\title{
FOGYATÉKOS EMBEREK HELYZETE NYÍREGYHÁZÁN ÉS TÉRSÉGÉBEN
}

\author{
HoRVÁth LÁSZló - KRIZSAi ANITA
}

\begin{abstract}
A wide range of services for disabled people can be found in Nyíregyháza. Their network-like cooperation has further opportunities in store. This presentation highlights the family-child relationship using the outcomes of a recent survey based on a questionnaire with 339 respondents from Nyíregyháza and 35 neighbouring settlements. We examined the social services provided by the local government to assist disabled people and their family members. The importance of early recognition of disability, local surroundings, network of services, as well as the tasks of professionals of health care, social care and education are also introduced. Finally, up-to-date approaches, the ways of family support and the challenges of residential homes are reviewed.
\end{abstract}

Keywords: disabled people, normalization, integration, early identification, family, Nyíregyháza

DOI: $10.19055 / \mathrm{ams} .2012 .3 / 3 / 11$

\section{BEVEZETÉS}

A fogyatékossággal való foglalkozás során általában elkülönül a felnőtt és a gyermek körüli szolgáltatás. Nyíregyházán megjelenik e kettő kapcsolata is, mely új lehetőségeket nyit a generációk közti együttmüködésre. (Pl.: Start Rehabilitációs Foglalkoztató és Intézményei Közhasznú Nonprofit Kft.) Az ellátások széleskörüek. Hálózatszerü együttmüködésük tapasztalható, melyben további lehetőségek rejlenek. A tanulmányban a gyermekek és a családok kapcsolatát és a nyíregyházi intézményrendszert részletezzük. A fogyatékos gyermek megszületése nagy feladat elé állítja a családot, de a társadalomnak is részt kell vállalnia a segítésben egészségügyi, szociális, oktatási és más feladatok ellátásával. A korszerü szemléletủ megközelítésről nemzetközi megállapodások szólnak. „Jövőképünk megvalósítása nemcsak a fogyatékos emberek, hanem a tár- 
sadalom egésze részére is előnyökkel jár. Az a társadalom, amelyik számos tagját kirekeszti, elszegényedett társadalom. A fogyatékos embereket segítő feltételek javítását célzó intézkedések mindenki számára rugalmas világ kialakítását eredményezik. Amit ma a fogyatékos ügy nevében megteszünk, annak a holnap világában mindenki számára értelme lesz." (EU 2002). A legújabb paradigmák között tartjuk számon az ENSZ közgyülése által elfogadott Fogyatékossággal Élö Személyek Jogairól Szóló Egyezményt. Preambulum: „...elismerve, hogy a fogyatékossággal élő gyermekek számára más gyermekekkel egyenlően kell biztosítani valamennyi emberi jog és alapvető szabadság gyakorlását. Emlékeztetve továbbá a Gyermek jogairól szóló egyezmény részes államainak e célból vállalt kötelezettségeire; meggyőződve arról, hogy a család a társadalom természetes és alapvető közösségi egysége, valamint, hogy a család jogosult a társadalmi és az állami védelemre. Továbbá hogy a fogyatékossággal élő személyeknek és családtagjaiknak meg kell kapniuk a szükséges védelmet és támogatást, amely lehetővé teszi, hogy a családok hozzájárulhassanak a fogyatékossággal élő személyek jogainak teljes és egyenlő gyakorlásához.” Ezeknek megfelelően vizsgáljuk a családi körülményeket és olyan magállapításokat teszünk, melyek a korszerü paradigmáknak megfelelnek. A fogyatékosság modern fogalmának megfelelően interdiszciplináris szemlélettel közelítjük meg ezt a témát.

Kutatási célunk volt feltárni, hogy a fogyatékos gyermek az egészségügyi és a szociális ellátást a családon belül vagy intézményben kapja-e meg. Megállapítani, hogy milyen módszerek szükségesek ahhoz, hogy a családok bekapcsolódhassanak az egészségügyi és szociális ellátásokba, mint partnerek. A kutatási eredmények alapján egy továbbképzési programot terveztünk összeállítani a fogyatékos gyermekekkel és családjaikkal foglalkozó szakemberek számára.

Alkalmazott módszerek. Kvantitatív kutatás, saját összeállítású kérdőívvel, 34 kérdés felhasználásával, mely hat részből áll: külön rész foglalkozik a válaszadó személyével, háztartásával, fogyatékos gyermekével, kapott vagy igényelt szolgáltatásokkal, a szabadidővel és a jövőbeli elképzelésekkel. A kutatás fontos része az irodalomelemzés. A fogyatékosság témakörével kapcsolatban sok tanulmány, könyv és nemzetközi dokumentum jelent meg. Az irodalomelemzés szempontja az volt, hogy a 20. század közepétöl milyen módon változott a fogyatékossággal élőkkel kapcsolatos szemlélet.

A kutatás résztvevöi. Olyan szülők, akiknek van fogyatékos gyermekük, akár a saját háztartásukban, akár bentlakásos intézményben nevelkednek. Természetesen a kérdőívre adott válaszok önkéntesek voltak, önbevalláson alapultak és a válaszadó felismerhetősége kizárt volt. A kérdőívek kitöltésére 2009-ben került sor. Nyíregyházáról és tágabb környezetéből, összesen 36 településéről kerültek ki a válaszadó szülök. Az elemszám 339 fö.

A kutatás megtervezésekor és lebonyolításakor hasonló problémákkal találkoztunk, mint a téma más kutatói. „A téma hazai kutatási előzménye viszonylag szerény. E kutatások egy része a népszámlálási adatok elemzéséhez, vagy egyedi adatfelvételhez kötődik.” (Fónai, Pásztor, Zolnai 2007). Magunk a fent leírt módszerekkel és mértéktartó elemzéssel kívántuk a kutatást szolgálni.

A kötet alapját szolgáló panelkutatáshoz szorosan kapcsolódik a mi kutatásunk is, a szerkesztő szándékával megegyezően: ,szeretnénk olyan tanulmányokat is megjelen- 
tetni, amelyek ugyan nem szerves részei a vizsgálatsorozatnak, mégis ahhoz tematiku san is kapcsolódva fontos és releváns információkat közölnek a városról, vagy olyan nagy ívü kutatás eredményei, amelyek kapcsolódnak a helyi közösséghez.” (Fábián G.)

\section{HELYI KÖRNYEZET ÉS HELYI KAPCSOLAT}

A válaszadó szülők legnagyobb problémája a közlekedés volt. A szolgáltatások színvonaláról, az anyagi körülményekről alkotott véleményeket is megelőzte a közlekedés problémája. Nemcsak a mozgássérültek esetében, hanem az összes érintett személy, beleértve a családtagokat, sőt a szakembereket is. Településnagyságtól függetlenül első helyen álló probléma. Az 1. táblázat mutatja azt, hogy milyen nagyságú lakóhelyen lakik a válaszadó a mintában.

\begin{tabular}{|l|c|c|}
\hline \multicolumn{1}{|c|}{ Lakóhelyének nagysága } & Létszám & Százalék \\
\hline 2000 fö alatti település & 44 & 13,0 \\
\hline 2001-5000 fös település & 62 & 18,3 \\
\hline 5001-10000 fös település & 52 & 15,3 \\
\hline 10001-50000 fös település & 79 & 23,3 \\
\hline 50000 fö feletti település & 102 & 30,1 \\
\hline Összesen & 339 & 100,0 \\
\hline
\end{tabular}

1. táblázat - A válaszadó lakóhelyének nagysága. Forrás: Háztartási panelvizsgálat 2010.

Legnagyobb létszámmal az 50 ezer fö feletti településeken lakó szülök szerepelnek (Nyíregyháza), létszámuk 102 fó, a válaszadók 30,1 százaléka. A települések nagyságát úgy választottuk ki, hogy az a jellemző településméreteket tükrözze. Így különösen fontos a kistelepülések beemelése a kutatásba, például 2000 fö alatti településen is találtunk 44 válaszadót. A további számok is azt mutatják, hogy minden településnagyságot jelentős súllyal kezeltünk a felmérés során. 79 válaszadó töltötte ki a kérdőívet 10 001-50 000 fös településeken, a válaszadók 23,3 százaléka. A kistelepülések egy további körében (2 001-től 5000 fös településig) 62 szülőnk van, a válaszadók 18,3 százaléka. A közepes nagyságúnak mondható településeken (5 001- 10 000-föig) 52 szülö töltötte ki a kérdöívet, a válaszadók 15,3 százaléka. Ahogy bemutattuk, a települések kiválasztása a megyében a településtípusok és méretek alapján történt, arra törekedtünk, hogy a mintába az egyes kategóriákból a tényleges eloszlás szerint kerüljenek be a települések. Ezt követően szakemberek bevonásával választottuk ki a családokat.

A válaszadók életkorát nem összesítettük, mert annak érdemi jelentése nincs. Döntő viszont az az adatsor, ami a szülök életkori skáláját mutatja és ez 25 évtöl 80 évig terjed. A 2. sz. táblázat azt mutatja, hogy a kutatómunkánk elején feltételezett korosz- 
tály (35-65-ig) szerepel legnagyobb mértékben a válaszadók között. Ettől fiatalabb válaszadónk mindössze három fö volt és ettől idősebb is csak 8 fö. A legjellemzőbb életkornak a 45 év körüli válaszadók tekinthetök, akiknek az aránya 38,1 százalék. A válaszadók másik nagy köre a 35 évesek csoportja, akiknek a létszáma 96 fö, a válaszadók 28,2 százaléka. Még jelentősnek mondható az 55 évesek csoportja is, mert az ö létszámuk 66 fö, a válaszadók 19,5 százaléka. Kisebb létszámban, 37 fővel jelenik meg a 65 évesek csoportja, a válaszadók 10,9 százaléka. A legidősebb válaszadónk a lekérdezés időpontjában 80 éves volt, létszáma 1 fő, a válaszadók 0,3 százaléka.

\begin{tabular}{|l|c|c|c|}
\hline Születési éve & Életkora (módusz) & Létszáma & Százalék \\
\hline 1981-1986 & 25 & 3 & 0,9 \\
\hline $1971-1980$ & 35 & 96 & 28,2 \\
\hline $1961-1970$ & 45 & 129 & 38,1 \\
\hline $1951-1960$ & 55 & 66 & 19,5 \\
\hline $1941-1950$ & 65 & 37 & 10,9 \\
\hline $1931-1940$ & 75 & 7 & 2,1 \\
\hline $1929-1930$ & 80 & 1 & 0,3 \\
\hline Összesen & - & 339 & 100,0 \\
\hline
\end{tabular}

2. táblázat - A válaszadók életkora. Forrás: Háztartási panelvizsgálat 2010.

A következő kérdés a válaszadó családi állapotával foglalkozott.

\begin{tabular}{|l|c|c|}
\hline Családi állapot & Létszám & Százalék \\
\hline Házasságban él & 239 & 70,5 \\
\hline Élettársi kapcsolatban él & 26 & 7,7 \\
\hline Egyedül neveli gyermekét & 74 & 21,8 \\
\hline Összesen & 339 & 100,0 \\
\hline
\end{tabular}

3. táblázat - A válaszadó családi állapota. Forrás: Háztartási panelvizsgálat 2010.

A kérdőíves felmérésünk egy nagyon fontos adatsora vonatkozik azokra a családokra, ahol fogyatékos gyermek él. A választ zárt kérdésekkel segítettük. A szerteágazó családi állapotok, csonka és többgenerációs családok hálójából mindössze három kategóriára voltunk kíváncsiak: a válaszadó házasságban vagy élettársi kapcsolatban él, vagy egyedül neveli gyermekét. Természetesen a gyermekek körül más rokonsági fokban ál- 
ló családtagok is lehettek, de témánk szempontjából ez a három kategória volt a legfontosabb. A fogyatékos gyermekek 70,5 százaléka olyan szülőkkel él együtt, akik házasságban élnek. Balogh Erzsébet és Fábián Gergely tanulmányában is azt olvashatjuk, hogy a családtagokra számíthatnak leginkább a megkérdezettek, ha problémájuk van. (Balogh, Fábián)

\section{A válas zadó családi állapota}
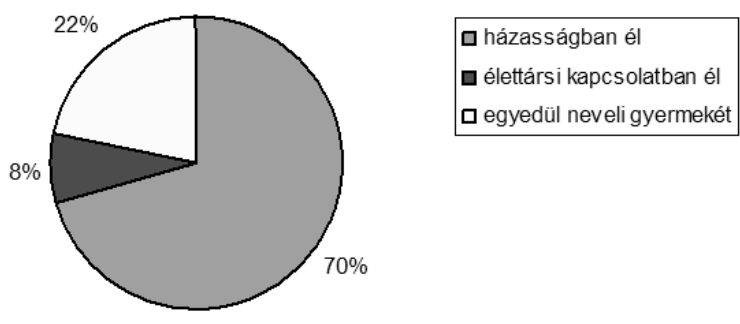

1. ábra - A válaszadó családi állapota.

Fábián és Takács tanulmánya alapján a jövedelmi kategóriák és a háztartás nagyság összehasonlításával mutat rá a téma fontosságára a fogyatékos gyermeket nevelő családok esetében is: „,...szignifikáns eltérés mutatkozik az egyes csoportok esetében a háztartásnagyság tekintetében. Míg az átlagos háztartásnagyság a városban 2.98 fö, addig az első és a második decilisek esetében 4.03, illetve 3.62 fö. Ezzel szemben a legkedvezőbb helyzetü 9. és 10 . deciliseknél 2.29 , illetve 2.02 fö. ...A magasabb létszámú háztartásnagyság az esetek döntő részében a háztartásban élő és 18 évesnél fiatalabb korosztályokból adódik....Ezt erősíti meg az a tény is, hogy a gyermeket nevelö háztartások általában kedvezőtlenebb helyzetben vannak a gyermektelenekkel szemben... A gyermeket nevelő háztartások nagyobb valószínüséggel tartoznak a kedvezőtlenebb jövedelmű csoportokba, mint a gyermektelen háztartások. " (Fábián, Takács)

Normalizált körülmények között (Nirje, Perrin 1998) fontos az emberek számára az utazás. Egy-egy éjszakát más településen, rokonoknál, táborban tölteni. Ezt is megnéztük, hogy a fogyatékos gyermekek elérik-e ezt a lehetöséget.

A gyermekek 85,8 százaléka (!) nem is volt ilyen táborban. Ez 291 esetet jelent. Ez úgy adódhatott össze, hogy nemcsak a családban felnövekvő gyermekek maradnak ki a táborokból, hanem még a bentlakásos intézményben nevelkedő gyermekek sem jutnak el teljes számban különböző táborokba. A gyermekeknek mindössze 14,2 százaléka jutott el valamilyen táborba. Ez nagyon alacsony szám, pedig még az 1-2 napos táborokat is tartalmazza. A legalább 1 hetes táborba eljutó gyermekek aránya mindössze 6,8 százalék.

Az előbbi kérdésnek lehet egy családi változata is, miszerint a gyermek környezet változását, az jelenti, hogy egy pár éjszakát más rokonoknál tölt. Ez még könnyebben 
megszervezhető lenne, ha a társadalom integrált és a családi segítségek rendelkezésre állnak. Azonban a kutatás azt mutatja, hogy nem sokkal jobb a kép, hiszen itt is 274 fö azon gyermekek köre, akik egyetlen éjszakát sem töltöttek másutt, külön rokonoknál. Ez a gyermekek 80,8 százaléka. Ha ezekhez az adatokhoz hozzávesszük, hogy kutatásunkban felnőtt korú gyermekkel is nagy számban foglalkozunk, akkor még rosszabbnak mondható ez a szám. A legalább egy hetet rokonoknál töltők száma némileg magasabb a táborban töltött napok számához képest, mert itt 39 fő szerepel, ez a válaszadók 11,5 százaléka. Ez sem felel meg a normalizáció elvének, de valamivel nagyobb, mint a táborban töltött hasonló arány, mely 6,8 százalék. A táblázat azt mutatja, hogy van 10 szülö, akinek a gyermeke 16-50 éjszakát töltött külön, rokonoknál, ez a válaszadók 2,9 százaléka.

\begin{tabular}{|l|r|r|}
\hline Éjszakák száma & Létszám & Százalék \\
\hline 0 & 291 & 85,8 \\
\hline $1-6$ & 25 & 7,4 \\
\hline $7-15$ & 23 & 6,8 \\
\hline Összesen & 339 & 100,0 \\
\hline
\end{tabular}

4. táblázat - Fogyatékos gyermekének táborban töltött ideje. Forrás: Háztartási panelvizsgálat 2010.

\begin{tabular}{|l|r|r|}
\hline Éjszakák száma & Létszám & Százalék \\
\hline 0 & 274 & 80,8 \\
\hline $1-6$ & 26 & 7,7 \\
\hline $7-15$ & 29 & 8,6 \\
\hline $16-50$ & 10 & 2,9 \\
\hline Összesen & 339 & 100,0 \\
\hline
\end{tabular}

5. táblázat - Fogyatékos gyermekének rokonoknál töltött éjszakáinak száma. Forrás: Háztartási panelvizsgálat 2010.

Ha valakinek a gyermeke bentlakásos intézményben él, akkor a kapcsolattartás módját és gyakoriságát lényegesen befolyásolja az intézmény és a lakóhely távolsága. Ezt a kérdést is feltettük annak a 68 gyermek szüleinek, akiknek gyermekei bentlakásos intézményben nevelkednek.

A kilométerben mért távolság 1-2 kilométertől kezdve 400 kilométerig terjedt. Egy kis országban a $400 \mathrm{~km}$-es távolság szinte csak akkor képzelhető el, ha a szülö az ország egyik sarkában él, a gyermek pedig a másik sarkában kap elhelyezést. Normalizáltnak tekintjük a $60 \mathrm{~km}$-en belüli távolságot, amelyek átlagos közlekedési körülményt alapul véve rendszeresen látogathatóak. Ez 46 gyermek esetében teljesül. Az 
összes többi esetben rohamosan nő a távolság 100, 200, 300, sőt 400 km-re. Ezekben az esetekben a rendszeres fizikai kapcsolattartás lehetetlenné válik, bár a modern technikával most újabb lehetőségek nyílnak meg, mint például a mobiltelefon vagy az internet. A normalizáció elvének mégis az felelne meg, ha ezen gyermekek családjuk közvetlen környezetében kapnák meg ezt a szolgáltatást.

\begin{tabular}{|l|r|r|}
\hline Távolság/ km & Létszám & Százalék \\
\hline $1-10$ & 12 & 18 \\
\hline $11-20$ & 6 & 9 \\
\hline $21-40$ & 19 & 28 \\
\hline $41-60$ & 9 & 13 \\
\hline $61-80$ & 11 & 16 \\
\hline $81-100$ & 3 & 4 \\
\hline $101-200$ & 4 & 6 \\
\hline $201-300$ & 2 & 3 \\
\hline $301-400$ & 2 & 3 \\
\hline Összesen & 68 & 100,0 \\
\hline
\end{tabular}

6. táblázat - A bentlakásos intézmény és a lakóhely távolsága. Forrás: saját felmérés.

A táblázat azt is mutatja, hogy a leggyakoribb távolság a bentlakásos intézmény és a szülők lakóhelye között a 21-40 km, 19 fö esetében, ez a válaszadók 28 százaléka. Ki fejezetten kis távolságnak tekinthető 12 szülö esetében az $1-10 \mathrm{~km}$, a válaszadók 18 százaléka. 20 szülö esetében 41-80 km-ig terjedő távolság szerepel a táblázatban, a válaszadók 29 százaléka. Igen nagy távolságok is szerepelnek, $100 \mathrm{~km}$ fölötti mértékben 8 esetben, a válaszadók 12 százaléka. 2 esetben találtunk 301-400 km-es távolságot is, a válaszadók 3 százaléka.

\section{A FOGYATÉKOSSÁG MEgÁllapítÁSA}

A korai fejlesztésről (Czeizel, Gallai 2000.) többet beszélünk, de a korai felismerés nélkül ez nem müködhet. A korai felismerés nem a specialista szakembernél kezdődik, hanem a helyi közösségben, a családban, az alapellátási szakembereknél. Viszont már ezeken a helyeken is csak azok jelennek meg, akik közlekednek: iskolába, egészségügyi és szociális intézményekbe eljutni még a helyi környezetben is csak közlekedéssel lehet /térségi ellátások, körzetesített szolgáltatások, utazó gyógypedagógusok stb./ 
A fogyatékosság megállapítása nem egyszerü kérdés. A fogyatékosságnak a kutatások szerint genetikai, nőgyógyászati, szülészeti okai is lehetnek. Születés után, komplex vizsgálatok és elemzések alapján bizottságok állapítják meg a fogyatékosság tényét és típusát.

\begin{tabular}{|l|c|c|}
\hline Megállapítást végző & Létszám & Százalék \\
\hline születés elött orvos & 10 & 2,9 \\
\hline születés közben orvos & 53 & 15,6 \\
\hline születés után bizottság & 189 & 55,8 \\
\hline más állapította meg, mégpedig & 87 & 25,7 \\
\hline összesen & 339 & 100,0 \\
\hline
\end{tabular}

7. táblázat - A fogyatékosság megállapítását végző személy. Forrás: Háztartási panelvizsgálat 2010.

\section{A fogyaték os ság m egállapitását végzõ személy}

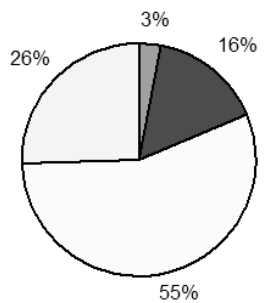

$$
\begin{array}{|l|}
\hline \square \text { születés elött orvos } \\
\square \text { születés közben orvos } \\
\square \text { születés után bizottság } \\
\square \text { más állapitotta meg, mégpedig }
\end{array}
$$

2. ábra - A fogyatékosság megállapítását végző személy.

A fogyatékosság megállapítását szakember végezte 252 esetben, a válaszadók 74 százalékánál. A belső arányokra jellemző, hogy a születés előtt mindössze a fenti esetek 3 százalékában volt fogyatékosság megállapítása. A fogyatékosságra vonatkozó kutatási eredmények szerint erre sokkal több lehetöség van, melyet egy évtizedek múlva lebonyolítandó kutatás talán már számokkal is tud bizonyítani. A válaszadók 26 százalékánál, tehát jelentős mértékben, nem ezek a szakemberek, testületek állapították meg elöször a fogyatékosság létét, hanem mások. Ezek között szerepelnek rokonok, szomszédok, tehát olyan emberek, akik nem feltétlenül szakemberek. A fogyatékosság megállapításakor nagyon fontos adat, hogy akkor hány éves volt a gyermek.

A kérdőívre adott válaszok általában kerek években szerepeltek, melyeket mi változatlanul szerepeltetünk a táblázatban, illetve magasabb korosztályok esetében azokat összevontuk.

A 0-8 évesek tekintetében szinte minden év különbsége fontos számunkra. Ezért megkülönböztettük az 1 év alattiakat, akiknek a száma 76 fö és az arányuk is jelentős, 
22,4 százalék. Ebben a csoportban a szülészeti, csecsemőgondozási és egészségügyi feladatok kiemelkedő jelentőségüek. Ha a gyermekek életkorát a 0-3 évre összesítjük, akkor már a megkérdezettek 67,2 százalékát kapjuk meg. Ez azért fontos, mert a korai felismerésnek ez az életkor nevezhető az optimális szakaszának. Vannak olyan fogyatékossági csoportok, amelyek jóval hamarabb is felismerhetők, de a későbbi diagnosztizálás már hátráltatja a gyermek korai fejlesztését. A magyarországi hivatalos dokumentumok szerint 0-5 év közé teendő a korai fejlesztés és korai felismerés. Ide tartozik a válaszadók 81,7 százaléka. De még ezek után is marad 18,3 százalék, akik esetében a korai felismerés elmaradt, így a korai fejlesztés is lehetetlenné vált. Remélhetjük, hogyha néhány év múlva ugyanilyen felmérést végzünk, akkor erre a kérdésre már csak 6 éven aluli adatokat fogunk kapni, mert a jelenlegi egészségügyi, szociális és oktatási szolgáltatásoknak kiemelt feladata a korai felismerés és a korai fejlesztés. Jelenleg a táblázat azt mutatja, hogy 6 éves korban még 20 fö, 7 éves korban 16 fó és 8 éves korban is még 12 fö károsodásának a felismerése ilyen későn történt meg. A kérdőíves kutatás során találtunk 9 és 21 év közötti diagnosztizálásokat is, összesen 14 esetben, a válaszadók 2,1 százaléka.

\begin{tabular}{|l|c|c|l|c|c|}
\hline Év & Létszám & Százalék & Év & Létszám & Százalék \\
\hline 1 év alatt & 76 & 22,4 & 7 & 16 & 4,7 \\
\hline $1-3$ & 152 & 44,8 & 8 & 12 & 3,5 \\
\hline 4 & 26 & 7,7 & $9-12$ & 7 & 2,1 \\
\hline 5 & 23 & 6,8 & $13-18$ & 5 & 1,5 \\
\hline 6 & 20 & 5,9 & $19-21$ & 2 & 0,6 \\
\hline & & & Összesen & 339 & 100,0 \\
\hline
\end{tabular}

8. táblázat - A gyermek életkora a fogyatékosság megállapításakor. Forrás: Háztartási panelvizsgálat 2010.

A gyermek életkora a fogyatékos ság m egállapitásak or

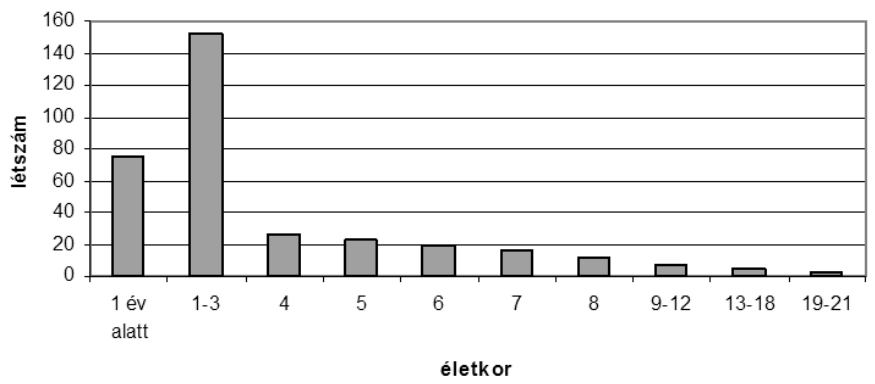

3. ábra - A gyermek életkora a fogyatékosság megállapításakor. 
4.

\section{A SZÜLŐK ÁLTAL MEGFOGALMAZOTT PROBLÉMÁK}

Az elérési utak fontosságát jelzik az alábbi szülői megfogalmazások is. A kérdőív utolsó kérdése nyílt kérdés formájában kérdezte meg, hogy melyek a legnagyobb problémái gyermekének nevelésével, ellátásával kapcsolatban. Nagyon sok fajta választ kaptunk, melyeket csoportosítottuk annak érdekében, hogy a feldolgozásuk lehetséges legyen.

A közlekedéssel összefüggő példák

- a településünkön nincs lehetőség sem fejlesztésre, sem foglalkoztatásra,

- autót kell fenntartani, hogy gyermekét meglátogathassa,

- az iskola messze van a lakóhelytöl,

- az iskolába való eljutás okoz gondot,

- csak autóval tudja hozni-vinni,

- $\quad$ iskolába minden nap autóval viszi, anyagilag megterhelö,

- $\quad$ szállítás, fejlesztő programokból több kellene.

A családok túlterheltsége

- 24 órás ápolásra szorul gyermeke, fáradt, segítségre lenne szüksége,

- a gyermek ápolásával egy bezárt világban érzi magát,

- a férje halála óta nem tudja felvállalni gyermeke gondozását.

Pénzzel, anyagiakkal kapcsolatos problémák

- a megélhetésük nehézkes, a gyermekének megfelelő szemüvegre lenne szüksége,

- alacsony a bére, így nem tud mindent megadni a gyermekének,

- a fejlesztést szolgáló úszást anyagilag nem engedhetik meg,

- $\quad$ anyagi természetủek a problémái, nem megoldott az iskolába járás, a támogató szolgálat sem olcsó,

- autót kell fenntartani, hogy gyermekét meglátogathassa,

- pénznélküliség és az állandó munka hiánya.

A szolgáltatásokkal kapcsolatos elvárások

- 16 óráig el kell hozni a gyermeket az iskolából és a szüneteket is nagyon nehéz megoldani,

- az intézmény nyitva tartása és a munkaideje nehezen egyeztethető össze,

- ha a településünkön lenne nappali ellátást nyújtó intézmény, akkor hazavihetné a gyermekét,

- a nappali foglalkoztatóban több éves a várólista,

- ha szeretne 1-2 napra elmenni, tudja hova éjszakára elhelyezni,

- napközi otthonos ellátás esetén otthon nevelhetné gyermekét,

- nem veszik fel öket óvodába, de csak az óvodásoknál jár fejlesztő foglalkozás,

- pszichológus hiánya az iskolában, külön torna szakkör hiánya. 
A családi kapcsolatok

- megtanuljon boldogulni akkor is, ha már a szülő nem lesz,

- a második házassága nehezen viseli el az első házasságából született fogyatékos gyermeket,

- többi családtag és a hozzá tartozók kommunikációhiánya,

- $\quad$ szocializáció, kommunikáció.

A szülöi megfogalmazásokból kiolvasható, hogy a szemléleti, anyagi problémák és a különböző szolgáltatások megváltoztatása egyaránt foglalkoztatja a szülőket. A szülők által megfogalmazott problémák első három köre (közlekedés, túlterheltség, anyagiak) megegyeznek a téma más kutatóinak eredményeivel. (Fónai, Pásztor, Zolnai 2007). A családok életkörülményeit a fenti helyzetek együttes, összehangolt megváltoztatásával lehet javítani.

\section{SZOLGÁLTATÁSOK NYÍREGYHÁZÁN}

A Nyíregyházára vonatkozó szolgáltatási adatokat egyrészt a fogyatékos személyeket megillető pénzbeli és természetbeni juttatások statisztikai kimutatása, másrészt a velük foglalkozó érdekvédelmi szervezetek nyilvántartásai, s a részükre szociális szolgáltatatást nyújtó állami, nem állami és egyházi szervezetek országos nyilvántartásba rögzített adatai alapján becsülhetjük meg.

\begin{tabular}{|c|c|c|c|c|c|c|}
\hline \multicolumn{2}{|c|}{ A támogatás megnevezése } & 2006 & 2007 & 2008 & 2009 & 2010 \\
\hline \multicolumn{2}{|c|}{ fogyatékossági támogatás } & 8.895 & & 7.785 & & \\
\hline \multicolumn{6}{|c|}{ Súlyosan mozgáskorlátozott személyek közlekedésével kapcsolatos támogatások } & \\
\hline \multicolumn{2}{|c|}{ átalakítási támogatás } & 3 & 4 & 6 & 2 & 3 \\
\hline \multicolumn{2}{|c|}{ szerzési támogatás } & 297 & 204 & 201 & 111 & 81 \\
\hline \multicolumn{2}{|c|}{ közlekedési támogatás } & 1662 & 1453 & 1274 & 1046 & 984 \\
\hline \multicolumn{6}{|c|}{ Szociális ellátás } & \\
\hline \multirow{5}{*}{$\begin{array}{l}\text { Ápolási } \\
\text { díj } \\
\text { összesen }\end{array}$} & Fokozott ápolás & 105 & 177 & 170 & 183 & 196 \\
\hline & Súlyosan fogyatékos & \multirow[t]{3}{*}{220} & \multirow[t]{3}{*}{222} & 142 & 189 & 206 \\
\hline & Halmozottan fogyatékos & & & 15 & 19 & 22 \\
\hline & $\begin{array}{l}\text { Tartósan beteg } 18 \text { év alattit } \\
\text { ápoló }\end{array}$ & & & 96 & 76 & 96 \\
\hline & $\begin{array}{l}\text { Tartósan beteg } 18 \text { év felettit } \\
\text { ápoló }\end{array}$ & & & 393 & 324 & 344 \\
\hline
\end{tabular}

9. táblázat - A fogyatékos személyek támogatásaiban részesítettek száma Nyíregyházán (fö). Forrás: Magyar Államkincstár és a Polgármesteri Hivatal, Nyíregyháza 201. 
Az érdekvédelmi szervezetek tagsága magasabb létszámú. Az eltérést a fogalmi meghatározások különbözősége okozhatja. Előfordulhat, hogy például egy nagyothalló személy nem részesül semmilyen támogatásban, mivel a jogosultsági feltételeknek nem felel meg, viszont tagja lehet a siketek és nagyothallókat tömörítő szervezetnek.

Nyíregyházán a fogyatékos személyek részére számos szolgáltató/intézmény nyújt alapszolgáltatást. A Szociális Gondozási Központ adatai szerint házi segítségnyújtásban részesülők közül 181 fő mozgásában korlátozott, 35 fő látássérült, 44 fő hallássérült, 9 fö értelmi fogyatékos, 103 fö halmozottan sérült (átfedések lehetnek).

A 2003. év óta bevezetett támogató szolgáltatás igen elterjedt. Az önkormányzati fenntartású intézmények mellett számos nem állami (alapítványok, egyesületek) és egyházi szervezet vállalta e formában a fogyatékos személyek ellátását. 2008-ban jelentős változás történt e szolgáltatás müködtetése és finanszírozása A 191/2208. (VII.30.) Korm.rendelet alapján a támogató szolgáltatás és a közösségi ellátás biztosítása pályázati rendszerben történik. Egy fenntartó azonos vagy részben azonos ellátási területen szolgáltatásonként egy szolgáltató támogatására nyújthat be pályázatot. A finanszírozás alaptámogatásból és teljesítménytámogatásból áll.

E jogszabályi változás következménye a támogató szolgálatok integrálása. Míg korábban 11 fenntartó 17 támogató szolgálata nyújtott ellátást, jelenleg 11 szolgáltató 11 támogató szolgálata müködik. Az ellátottak létszáma növekedett. 2007-ben 340 főt segítettek Nyíregyházán, 2009-ben 544 ellátottal kötöttek megállapodást a szolgáltatók. A létszámnövekedés hátterében egyrészt a felmerülö, kielégítetlen szükségletek, másrészt a szolgáltatás igénybevételének kedvező lehetősége áll. 2007-ben bevezetésre került a szociális rászorultság fogalma, ami a támogató szolgáltatás esetében azt jelenti, hogy a súlyosan fogyatékos személy ${ }^{1}$ a szolgáltatást - személyi segítést és szállító szolgáltatást is- ingyenesen veheti igénybe.

A jogszabály alapján valamennyi fogyatékossági csoportba (mozgás, látás, hallás, értelmi) tartozó ellátott részére kell a szolgáltatást biztosítani, az ellátottak jelentős része azonban mozgáskorlátozott (az ellátottak 43,3\%-a), értelmi sérült (az ellátottak 24,6 \%-a) vagy látássérült (19,5\%). Az igénybevétel önkéntes, nyilvánvalóan ott igénylik az ellátást, amely szervezettel egyébként is kapcsolatban áll a kliens, illetve ennek hiányában a kapott információ (családi, ismerősi kapcsolat, egészségügyi intézmények szórólapjai) alapján választhat a szolgáltatók közül. Ilyen értelemben a civil szervezetek jelenléte választási lehetőséget, alternatívát jelent a kliensek, ellátottak számára.

A fogyatékos személyek nappali ellátását nyújtó intézmények a fogyatékos emberek részére szociális, egészségi, mentális állapotuknak megfelelö napi életritmust biztosító szolgáltatást nyújtanak, a helyi igényeknek megfelelő közösségi programokat szerveznek, valamint helyet biztosítanak a közösségi szervezésủ programoknak, csoportoknak. A nappali ellátást nyújtó intézmények nagy része szociális foglalkoztatás megszervezésével hasznos, értelmes időtöltést és jövedelemszerzési lehetőséget biztosít ellátottai részére.

1 Súlyosan fogyatékos: az 1993. évi III. törvény 65/C § (5) bek. alapján a fogyatékossági támogatásban, a vak személyi járadékban illetve a magasabb összegü családi pótlékban részesülő személy. 


\begin{tabular}{|l|l|}
\hline \multicolumn{1}{|c|}{ Fenntartó } & $\begin{array}{c}\text { A szolgáltató/intézmény megnevezése, } \\
\text { létszáma }\end{array}$ \\
\hline Nyíregyháza Megyei Jogú Város Önkormányzata & $\begin{array}{l}\text { Mentálhigiénés Központ (,Esély”Támoga- } \\
\text { tó Szolgálat) 64 fö }\end{array}$ \\
\hline ÉFOÉSZ Szabolcs-Szatmár-Bereg Megyei Egyesülete & $\begin{array}{l}\text { ÉFOÉSZ Szabolcs-Szatmár-Bereg Megyei } \\
\text { Egyesülete Támogató Szolgálat }\end{array}$ \\
\hline $\begin{array}{l}\text { Mozgáskorlátozottak Szabolcs-Szatmár-Bereg Megyei } \\
\text { Egyesülete }\end{array}$ & „Önálló Életvitelért” Támogató Szolgálat \\
33 fö
\end{tabular}

10. táblázat - Támogató szolgálatok Nyíregyházán 2011. Forrás: Polgármesteri Hivatal, Nyíregy háza 2011.

\begin{tabular}{|l|l|}
\hline \multicolumn{1}{|c|}{ Fenntartó } & \multicolumn{1}{|c|}{ Intézmény/férőhely } \\
\hline Nyíregyháza Megyei Jogú Város Önkormányzata & Mentálhigiénés Központ (ÉNO 35 férőhely) \\
\hline Rókahegyi Agapé Alapítvány & $\begin{array}{l}\text { Szent Rita Pszichiátriai Betegek és Fogyaték- } \\
\text { kal Élök Nappali Intézménye (35 féröhely fo- } \\
\text { gyatékosok számára) }\end{array}$ \\
\hline Együtt Veled Alapítvány & Szent József Védőotthon (20 féröhely) \\
\hline Nyíregyháza - Kertvárosi Református Egyházközség & Irgalmas Samaritánus ÉNO (20 féröhely) \\
\hline Magyar Sclerosis Multiplex Betegekért Alapítvány & Nyíregyházi SM Centrum (27 férőhely) \\
\hline Omnis Alapítvány & $\begin{array}{l}\text { Szent István Értelmi Fogyatékosok Nappali } \\
\text { Intézménye (25 féröhely) }\end{array}$ \\
\hline $\begin{array}{l}\text { Mozgáskorlátozottak Szabolcs-Szatmár-Bereg Me- } \\
\text { gyei Egyesülete }\end{array}$ & $\begin{array}{l}\text { Nefelejcs Fogyatékos Személyek Nappali In- } \\
\text { tézménye(40 féröhely) }\end{array}$ \\
\hline $\begin{array}{l}\text { Szent Kamill Életet az Életnek Közhasznú Alapít- } \\
\text { vány }\end{array}$ & $\begin{array}{l}\text { Szent Kamill Rehabilitációs Központ Értelmileg } \\
\text { Akadályozottak Nappali Otthona (25 férőhely) }\end{array}$ \\
\hline
\end{tabular}

11. táblázat - Nappali ellátást nyújtó intézmények Nyíregyházán 2011. Forrás: Polgármesteri Hivatal, Nyíregyháza 2011. 
A fogyatékos személyek tartós bentlakásos elhelyezése elsősorban lakóotthoni ellátás illetve a fogyatékos személyek otthona keretében biztosítható. A lakóotthon nyolc-tizenkettő, fogyatékos személyt befogadó intézmény, amely az ellátást igénybevevő részére életkorának, egészségi állapotának és önellátása mértékének megfelelő ellátást biztosít. A lakóotthon szolgáltatásai
a) étkezés,
b) munka jellegü foglalkoztatás megszervezése,
c) pénzkezeléssel kapcsolatos segítségnyújtás,
d) egészségügyi, mentálhigiénés alapszolgáltatás (tanácsadás, életvitel javítá- sát segítő programok),
e) szabadidős programok szervezése (kirándulás, rendezvények).

A fogyatékos személyek otthonában az önmaguk ellátására nem, vagy csak folyamatos segítséggel képes fogyatékos személyek napi legalább háromszori étkeztetése, szükség szerint ruházattal, illetve textíliával való ellátása, mentális gondozása, egészségügyi ellátása valamint lakhatása biztosított. A fogyatékos személyek otthonába az a fogyatékos személy helyezhető el, akinek oktatása, képzése, foglalkoztatása, valamint gondozása csak intézményi keretek között lehetséges.

\begin{tabular}{|c|c|c|}
\hline Szolgáltatás & Fenntartó & Intézmény/férőhely \\
\hline \multirow[t]{4}{*}{ Lakóotthon } & $\begin{array}{l}\text { Nyíregyháza Megyei Jogú } \\
\text { Város Önkormányzata }\end{array}$ & $\begin{array}{l}\text { Mentálhigiénés Központ (Kék Szirom Lakó- } \\
\text { otthon } 10 \text { férőhely) }\end{array}$ \\
\hline & Patrónus Egyesület & Patrónus Egyesület Lakóotthona (8 féröhely) \\
\hline & $\begin{array}{l}\text { Magyarországi Református } \\
\text { Egyház }\end{array}$ & $\begin{array}{l}\text { Magdaléneum Fogyatékos Személyek ápoló- } \\
\text { gondozó célú Lakótthona I.,II. } \\
\text { ( } 8+8 \text { férőhely) }\end{array}$ \\
\hline & $\begin{array}{l}\text { Szent Kamill Életet az Élet- } \\
\text { nek Közhasznú Alapítvány }\end{array}$ & $\begin{array}{l}\text { Szent Kamill Rehabilitációs Központ Lakó- } \\
\text { otthona (13 féröhely) }\end{array}$ \\
\hline \multirow[t]{3}{*}{$\begin{array}{l}\text { Fogyatékosok } \\
\text { Otthona }\end{array}$} & $\begin{array}{l}\text { Nyíregyháza Megyei Jogú } \\
\text { Város Önkormányzata }\end{array}$ & Szivárvány Idősek Otthona (30 férőhely) \\
\hline & $\begin{array}{l}\text { Nyíregyháza - Kertvárosi Re- } \\
\text { formátus Egyházközség }\end{array}$ & Anna Szeretetotthon (12 férőhely) \\
\hline & $\begin{array}{l}\text { Magyarországi Református } \\
\text { Egyház }\end{array}$ & $\begin{array}{l}\text { Magdaléneum Fogyatékosok Református } \\
\text { Ápoló-gondozó Otthona ( } 84 \text { fö) }\end{array}$ \\
\hline
\end{tabular}

12. táblázat - Tartós bentlakásos intézmények Nyíregyházán 2011. Forrás: Polgármesteri Hivatal, Nyíregyháza 2011. 


\section{ÖSSZEGZŐ JAVASLATOK A GYAKORLAT SZÁMÁRA}

Az alábbiakban olyan konkrét javaslatokat fogalmazunk meg, melyek a korszerü elveknek, a kérdőíves kutatás alapján a szülők véleményének megfelelnek. Ezek egy része esetenként müködik, de a teljes, minden gyerekre, családra, intézményre való kiterjesztése szükséges. Ezen javaslatok nagy része a családban és a bentlakásos intézményben élő gyermek esetében is megvalósítható. A normalizáció jegyében ugyanis a lehető legkevesebb eltérés van a két helyszín között. Ez a jelenlegi bentlakásos intézmények nagy arányú belső átalakítását, tartalmi gazdagítását kívánja meg.

Külön kezeljük a terhesség elött és annak a 20. hetéig felismerhető genetikai és más rendellenességeket, illetve annak esélyeit. Ebben a szakaszban a tudomány többre képes, mint amennyire elterjedtek ezek a vizsgálatok. A kérdőíves felmérés azt bizonyította, hogy a korai felismerés még a 0-5 éves időszakban sem teljes, ami a jelenlegi szabályok alapján kívánatos lenne. A genetikai tanácsadás és a korai felismerés szakemberei tudnának segíteni a prevencióban és a korai felismerésben, fejlesztésben. A korai felismerés soha nincs elég korán. A tudomány mindenkori állapotának megfelelöen egyre korábbra, akár a fogamzás előtti időre is tevődhet beavatkozás, például a szü lők felkészítésével és preventív szolgáltatásokkal.

A korai felismerés és fejlesztés is család központú. Információt adhat a család a szakembernek és viszont. A különböző szolgáltatások összeköthetők egymással és így a családi kapcsolatokat is erősíthetik. Korai fejlesztés nincs korai felismerés nélkül. Ezért az érdekelt oktatási, egészségügyi, szociális és szülöi szervezetek bevonásával meg kell szervezni a korai felismerés hálózatát.

Külön kezeljük a terhesség alatt és a szülés közben keletkezett sérüléseket, mert a prevenció itt kiemelt jelentőségű lehet. A várandósság alatt a betegségek megelőzése, az egészséges életmód segíthet. A családon belüli bántalmazás kiterjedhet a várandós nöre, a magzatra, melynek elkerülése szükséges. A szülés közben keletkezett sérülések megelözése az orvostudomány fontos feladata.

A fogyatékos személyekkel az életkori sajátosságnak megfelelően bánjunk. Az idősebb gyermekkel másként bánjunk, mint a kisebbel. Felnőtt korára éppen úgy felnőttként kezeljük, mint az ép társait.

A normalizáció jegyében a gyermekek lakószobája, privát szférája barátságos, a környezete inger gazdag. Akár családban, akár bentlakásos intézményben él.

A gyermek önrendelkezése kiterjed a hitéletére is. A vallásokkal való megismertetés és a feltételek biztosítása környezetének a feladata, de a gyermek életkorának megfelelö ütemben a döntés az önrendelkezése keretében alakuljon ki.

Általános szükséglet a fogyatékos gyermek szabadsága is. A családból menjen el szülők nélkül is kirándulni, táborozni, természetesen korának megfelelö felügyelettel. A bentlakásos intézményből mehessen haza, szabadságra és más helyekre kirándulni, táborozni. A normalizáció elvének az felel meg, ha az éves ciklusa is olyan, mint a többi gyermeké.

A szocializált gyermek ismeri a szokásos közlekedési eszközök mindegyikét. A tapasztalat azt mutatja, hogy sok esetben a fogyatékos gyermek nem ismer meg sokszor 
előforduló eszközöket, nem mutatják meg a használatát. A vonat, busz, villamos és más hasonló eszközök használata életének a része. Az ehhez szükséges felkészítést és támogatást a gyermek kapja meg.

A változatos társas környezet része a fogyatékos gyermek életének is. Családi körben sokszor tapasztalható az egy szülővel való szinte kizárólagos kapcsolatot, bentlakásos intézményben pedig a sorstársak és a személyzet az állandó kapcsolat. Mindkét szülővel, testvérekkel, nagyszülőkkel, más rokonokkal, iskolatársakkal, szomszédokkal gazdagabb a társas környezete.

A fogyatékos gyermek esetében is legyen kommunikáció a család tagjaival. Erre akkor is figyelni kell, ha a gyermek a családjában nő fel, de akkor is lehetőséget kell rá adni, ha bentlakásos intézményben. Az intézeti elhelyezés nem azt jelenti, hogy a családnak ilyenkor már nincs semmiféle szerepe. A rendszeres látogatás, együttes cselekvéssel fenntartja a családi kapcsolatot. Így megelőzhető, hogy az ellátott az intézetben szorongjon a család miatt, és a család is mentesül a terhek egy része alól.

A meglevő szolgáltatások ésszerü kihasználása és megközelíthetősége miatt, azokat érdemes lenne egy helyre vagy egymáshoz közelebb szervezni. Ez biztosítaná az átjárhatóságot és az összehangoltságot. A bentlakásos intézményekben jelentős szaktudás halmozódott fel, ezért szükséges köréjük szervezni a korszerü szolgáltatásokat is. Ehhez jelentős szemléletváltozásra van szükség. Biztosíthatnának módszertani szolgáltatásokat a szülők, oktatási intézmények számára. Szervezhetnének új szolgáltatásokat a családokban élő fogyatékos gyermek és környezete számára. Korai felismerés, korai fejlesztés, logopédus, gyógytornász, gyógypedagógus, masszőr, védőnő, szociális munkás segíthetné team munkában ezeket a tevékenységeket. Jelentős haszna lenne, hogy átjárhatók lennének a szolgáltatások és nem lenne közöttük merev elválasztás, mint most a bentlakásos intézményekben. A szülök számára könnyebbség lenne a kevesebb közlekedés, amit ma nagy tehernek tartanak.

A fogyatékos gyermekek és szüleik egyik legnagyobb problémája a közlekedés. Ez nem csak a mozgásfogyatékos gyermekeket érinti. Általánossá kell tenni e probléma megoldását. Magyarországon múködik a támogató szolgálat, melynek átalakításával kezelhető lenne ez a kérdés. A támogató szolgálat a fogyatékos személy önálló életvitelét elősegítő, a mindennapi szükségletei kielégítését célzó szolgáltatás. Célja a fogyatékos személyek saját lakókörnyezetében történő ellátása, a lakáson kívüli közszolgáltatások /egészségügyi, szociális, oktatási, munkavégzést segítő szolgáltatások/ elérésének segítése. A kliens önállóságának megőrzése mellett a lakáson belül is segítenek. Biztosítja a jelnyelvi tolmácsszolgálat elérhetőségét. A támogató szolgálat valamennyi tevékenységét tekintve hiánypótló szolgáltatás. Olyan szükségleteket elégít ki, ami az azt megelőző szociális ellátórendszer által (2003 elött) egyáltalán nem, vagy csak részben kielégített volt. További pozitívuma, hogy lehetővé teszi a sérültek számára lakóhelyközpontú szolgáltatások elérését. A szolgálat müködésének eredményeként javul a városokban és azok vonzáskörzetében élő sérült emberek életminősége.

A siketvak személyek számára tolmácsszolgáltatás biztosítása. Élnek olyan hallássérültek, akik nem jelnyelv használók, hiszen még gyermekkorukban veszítették el látásukat, így ők a Braille írást sajátították el. Náluk nem alkalmazható a jelnyelv, de hallássérülésük miatt a hangzó beszéd sem, mint más látássérült társaiknál. Ebben az eset- 
ben egy speciális, nemcsak kommunikációs, de a személyi segítő szerepet is felvállaló tolmács tud csak érdemben a segítségükre lenni. Olyan speciális kommunikációs módszereket kell alkalmazni, mint jelelés kéz a kézbe, a Braille kézbeírt változata, a beszélő szájállásának letapogatása.

Az autizmus felismerését és a hozzá kapcsolható szolgáltatásokat jelentősen fejleszteni kell. Nyíregyházán van olyan óvoda és iskola, ahol rendelkezésre áll a speciális szaktudás is, velük együtt a probléma korai felismerésére fel kell készíteni a szülöket, védőnőket, a bölcsődei gondozókat. A további segítésük minden közintézmény számára új feladatokat jelent. Az Állampolgári Jogok Országgyülési Biztosa is megállapította, hogy az autista emberek jogaival kapcsolatban visszásságot okoz az intézményrendszer alkalmatlansága. A befogadó társadalom megteremtésén túl a diagnosztikai háttér biztosítására, komplex fejlesztésre és szakemberekre van szükség. Az oktatásban dolgozók nem rendelkeznek kellő rálátással és képzettséggel ahhoz, hogy kezelni tudják az autizmussal élők igényeit és segíteni tudják beilleszkedésüket. Nem csak az általános pedagógusok, hanem a gyógypedagógusok felkészítését is ki kell terjeszteni az autista ember segítésére.

\section{ÖSSZEFOGLALÁS}

A fogyatékos emberek és családjaik segítése a nemzetközi, állami és helyi környezet figyelmébe került. Ezt bizonyítják a felhasznált dokumentumok, jogszabályok és a szolgáltató intézmények léte. Nyíregyházán is tapasztalható mindez.

A fogyatékosság korszerü definíciója szerint nyitott fogalom. Ezért fel kell készülni új jelenségek befogadására is. Ilyen a pszicho-szociális fogyatékosság megnevezése, a cselekvőképesség kizárása helyett a támogatott döntéshozatal beillesztése a segítő tevékenységek közzé. Folyamatos kutatómunka és a kliensek újszerü szükséglet hiányainak felismerése kell ahhoz, hogy a fejlödés e témában se rekedjen meg egy pillanatra sem.

A továbbfejlődés egyik kulcseleme a családok és az intézmények együttmüködésének felülvizsgálata. Ez komplex feladat. Az alapellátások bővítése, a bentlakásos intézmények átalakítása és a családokkal való kapcsolatainak erösítése, valamint a közöttük való átjárhatóság rugalmas biztosítása felel meg a felmért igényeknek és a korszerü normáknak.

Nyíregyházán egyre több fajta fenntartója van a fogyatékos embereket segítő intézményeknek. A városi, megyei és a környezö kisebb települések önkormányzatai mellett civil szervezetek, egyházak, kistérségek, kormányhivatalok, járási jellegü szerveződések egyre nagyobb mértékben vállalnak szerepet. A kliensek számára szóló összehangoltságot - az intézmények szervezeti önállóságának fenntartásával - egy hálózatszerü együttmüködés segítené. Minden érintett ágazat részt vételét szükséges biztosítani: egészségügy, közoktatás, szakképzés, foglalkoztatás, hatósági területek. Team munka, kliens életút követése, közös továbbképzések, esetmegbeszélések javíthatnák a munka kliensközpontú összehangoltságát. 


\section{IRODALOM}

1. Balla Gy.(2008.): A magyar intenzív neonatológiai ellátás jellemzői. In Gyermekorvos Továbbképzés, 2008/7. sz. 10-11. p. ISSN 1589-0309

2. Bass L.(2004.): Jelentés a súlyosan-halmozottan fogyatékos embereket nevelő családok életkörülményeiről. Kézenfogva Alapítvány, Budapest

3. Czeizel B., Gallai M.(2000.): A korai fejlesztés elméleti és gyakorlati tapasztalatai. In Fejlesztő Pedagógia, 2000/11. ISSN 0866-2495

4. Czeizel B., Gallai M.(2000.): A korai fejlesztés elméleti és gyakorlati tapasztalatai. In Fejlesztő Pedagógia, 2000/11. ISSN 0866-2495

5. Csányi Y. szerk. (2001.) Értelmileg és tanulásban akadályozott gyermekek integrált nevelése és oktatása (Útmutató szülőknek és szakértői bizottságoknak. ELTE GYFK, Budapest.

6. ENSZ (2006.). Fogyatékossággal élő személyek jogairól szóló egyezmény és az ahhoz kapcsolódó fakultatív jegyzőkönyv. ENSZ, 2006. december 13.

7. Európai Bizottság (2010.) Európai fogyatékosságügyi stratégia 2010-2020. Brüsszel, 2010.11.15.

8. EU Zöld Könyv (2005.) Brüsszel Az Európai Közösség Bizottsága, 2005. október 14. COM

9. Fábián G.(2006.): Öszülő társadalmak. In Imre Sándor-Fábián Gergely (szerk.): Öszülő társadalmak. DE-EFK, Nyíregyháza. ISBN 963-473-003-5

10. Fónai M, Pásztor E., Zolnai E.( 2007.): A fogyatékos emberek helyzete, életmódja és életkörülményei Hajdú-Bihar megyében. Esély, 2007/6. 87-119.o.

11. Horváth, L. (2010.): Early Identification of Disability Children. In Twenty Years of Health Care Education and Social Sciences at the Faculty of Health University of Debrecen. Nyíregyháza. Faculty of Health University of Debrecen. 60-75.p.

12. Horváth L.(2004.) Az alap- és szakosított ellátás viszonya a szociális munkában. In A humán erőforrás szerepe, fejlesztésének, hasznosításának lehetőségei az Európai Unióban. Szabolcs-Szatmár-Bereg Megyei Tudományos Közalapítvány, Nyíregyháza. 212-215.p. ISBN 9632142136

13. Horváth L.(2007.) Deficient Children in the Family. In Kontakt, ISSN 1212 4117

14. Horváth L.(2009.): Fogyatékos gyermekek intézménybe kerülésének - családból való kikerülésének okai. In Szociális munka az egészségügyben. Debreceni Egyetem Egészségügyi Kar - Kent School of Social Work University of Louisville, Nyíregyháza. 104-114.p. ISBN 9789634733485

15. Kosikné J.(1988.): Fogyatékos gyermekek szüleinek elképzelései gyermekeik jövőjéről. BGGYTF, Budapest.

16. Madridi Nyilatkozat. (2002.) EU, Madrid.

17. Nirje B., Perrin B.(1998.): A normalizációs elv és félreértelmezései. ÉFOÉSZ, Budapest. ISBN 963-03-5934-0 
18. Papp K., Horváth L. (2006.): Globalization and philanthrophy in nursing. In Nové trendy v osetrovatelství V. University of South Bohemia, Ceské Budejovice.

19. Szabó L.(2003.): A boldogság relatív - Fogyatékosság és szubjektív életminőség. Szociológiai Szemle, 2003/3. 86-106.o.

20. Perlusz A. szerk. (1995.): Fogyatékos gyermekek integrált nevelése hazai kísérletek tükrében BGGYTF, Budapest.

21. Pfeffer W.(1995.): A súlyos értelmi akadályozottak fejlesztésének alapvetés (szerk. Kedl M.) Bárczi Gusztáv Gyógypedagógiai Tanárképző Főiskola, Budapest.

22. Pordán Á. (1996.): Normalizált lakhatási lehetőségek útja értelmileg akadályozott emberek számára. In Rehabilitáció, 1996/3. ISSN 0866-479X

23. UNESCO.( 1994.) Salamancai nyilatkozat és Cselekvési Tervezet a sajátos nevelési igényü tanulók számára. Salamanca, 1994. június 7-10.

24. Tringer L.( 2000.): A család szerepe és a lelki egészség. In Vigília, 65 (8) 2000. ISSN 0042-6024

25. Vekerdy Zs.(2003.): A súlyos fogyatékosok, a halmozottan sérültek lehetőségei. OORI. Felelősség, együttmüködés - befogadó társadalom. Országos Szakmai Konferencia a Fogyatékossággal Élők Európai Éve alkalmából, Budapest, 2003.december 1-2. 


\section{A KÖTET SZERZÖI}

Dr. habil. Fábián Gergely tanszékvezető főiskolai tanár, dékán, Debreceni Egyetem Egészségügyi Kar

Malakucziné Póka Mária igazgató - Központi Statisztikai Hivatal, Debreceni Igazgatósága

Dr. Takács Péter Ph.D föiskolai docens Debreceni Egyetem Egészségügyi Kar

Dr. Szoboszlai Katalin Ph.D

főiskolai docens Debreceni Egyetem Egészségügyi Kar

Rusinné Fedor Anita

doktorjelölt adjunktus Debreceni Egyetem Egészségügyi Kar

Jóna György doktorandusz adjunktus Debreceni Egyetem Egészségügyi Kar

Jávorné Erdei Renáta doktoranda, gyakorlati oktató, Debreceni Egyetem Egészségügyi Kar

Patyán László doktorjelölt, főiskolai docens Debreceni Egyetem Egészségügyi Kar

Balogh Erzsébet doktoranda, föiskolai tanársegéd Debreceni Egyetem Egészségügyi Kar

Huszti Éva doktorjelölt adjunktus Debreceni Egyetem Egészségügyi Kar

Dr. Horváth László PhD föiskolai docens Debreceni Egyetem Egészségügyi Kar

Dr. Krizsai Anita irodavezető, Megyei Jogú Városi Polgármesteri Hivatal Nyíregyháza 